\title{
In-Place Oil Shale Resources Examined by Grade in the Major Basins of the Green River Formation, Colorado, Utah, and Wyoming
}

\author{
Using a geology-based assessment methodology, the U.S. Geological Survey estimated a total of 4.285 trillion \\ barrels of oil in-place in the oil shale of the three principal basins of the Eocene Green River Formation. Using \\ oil shale cutoffs of potentially viable (15 gallons per ton) and high grade (25 gallons per ton), it is estimated that \\ between 353 billion and 1.146 trillion barrels of the in-place resource have a high potential for development.
}

Oil shale in the Eocene Green River Formationincluding the Piceance Basin of northwestern Colorado, the Uinta Basin of northeastern Utah, and the Greater Green River Basin of southwestern Wyoming - is the world's largest known deposit of kerogen-rich rocks (Dyni, 2006). The total potential resource within these deposits, regardless of grade, is estimated in the most recent U.S. Geological Survey resourcein-place assessment to be 4.285 trillion barrels of oil (Johnson and others, $2010 \mathrm{a}$, b; Johnson and others, 2011). Although this assessment is one of the most comprehensive of its kind, with a database of nearly a half million measurements made on samples collected throughout the three principal basins, it is only an assessment of resource-in-place and does not attempt to address the issue of how much of the resource is recoverable.

Figures 1, 2, and 3 show frequency and cumulative oil shale resource distributions as a function of grade for the three principal basins; the axes of all three figures are equivalent to facilitate visual comparison. Figure 4 combines all three basins in a complimentary cumulative distribution plot. The following overall values were determined for the entire Green River Formation: 1.146 trillion barrels (27 percent) of the total resource in the Green River Formation would be considered recoverable at a grade cutoff of 15 gallons of oil per ton of shale (GPT), and 353 billion barrels ( 8 percent) would be considered recoverable at a grade cutoff of 25 GPT. Oil shale with this oil-generating potential ( $\geq 25$ GPT) is often described as high grade. These values are similar to previous estimates of recoverable oil shale resources in the Green River Formation (Bartis and others, 2005). Estimates of potentially viable ( $\geq 15$ GPT) and highgrade ( $\geq 25$ GPT) in-place oil shale resource for each basin are summarized in table 1 .

It is important to put these values into context with respect to world crude oil reserves and domestic United States consumption levels. The most current estimate of world crude oil proved reserves by the U.S. Energy Information Administration (2012a) is 1.342 trillion barrels. Inclusion of high-grade Green River Formation oil shale resources ( $\geq 25$ GPT) would increase this value by 26 percent, and adding all potentially viable oil shale ( $\geq 15$ GPT) would nearly double it. At the current rate of oil consumption in the United States, which is roughly 19 million barrels per day (U.S. Energy Information Administration, 2012b), high-grade Green River Formation oil shale resources represent a 50-year supply of oil. If the 15- to 25-GPT resource is included, then the prospective oil shale represents a 165 -year supply of oil for the United States. By these measures, the oil shale of the Green River Formation represents an enormous potential resource.

\section{Methods}

The oil shale resource in the Green River Formation that is likely to be developed is expected to be limited to locations where high concentrations of high-grade oil shale are present. In some cases, lower-grade oil shale, yielding at least 15 GPT, may be potentially viable and therefore targeted or developed along with high-grade material. Oil shale grade is determined by the Fischer assay method, which is used to measure oil yield under a particular set of pyrolysis conditions (American Society for Testing and Materials, 1980). The first step in developing an estimate of the recoverable resource in Green River Formation oil shale deposits is to take the grade-dependent limitations for development into account. To that end, the distribution data relating oil shale grade (GPT) to total oil yield (barrels of oil) was extracted from the assessment database for the Piceance, Uinta, and Greater Green River Basins. Average grade was calculated on a per acre basis for each of the stratigraphically defined rich and lean zones identified in previous studies (Johnson and others, 2010 a, b; Johnson and others, 2011) throughout each of the three basins. These limits on the resolution of the analysis are consistent with the data density and stratigraphic resolution identified during the assessment. The total resource represented by each grade ( 0 to 50 GPT at 1 GPT increments) was summed to generate datasets of grade versus resource for each basin by zone. 


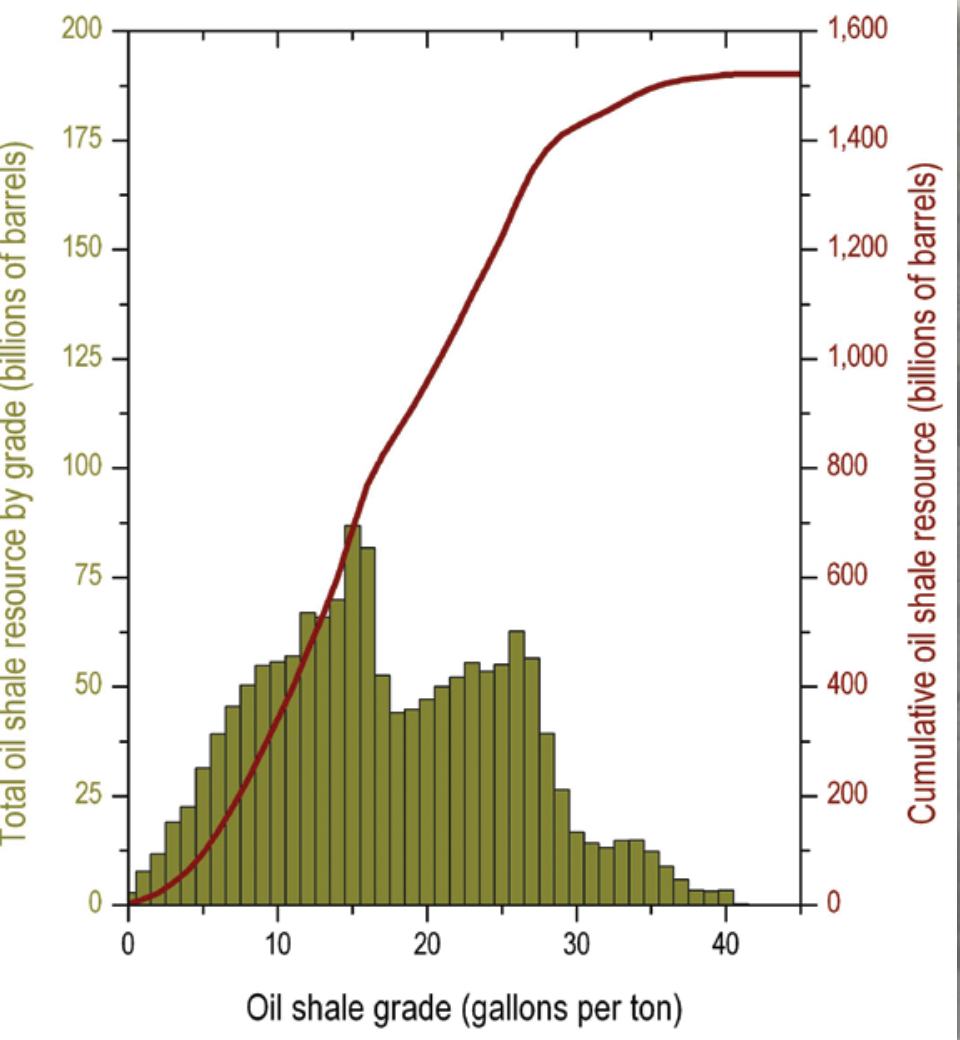

Figure 1. Oil shale resource in-place distribution plot for the Piceance Basin. The bars represent the total resource in the basin for a particular grade. The line represents the cumulative resource in place that includes all resource up to a patt

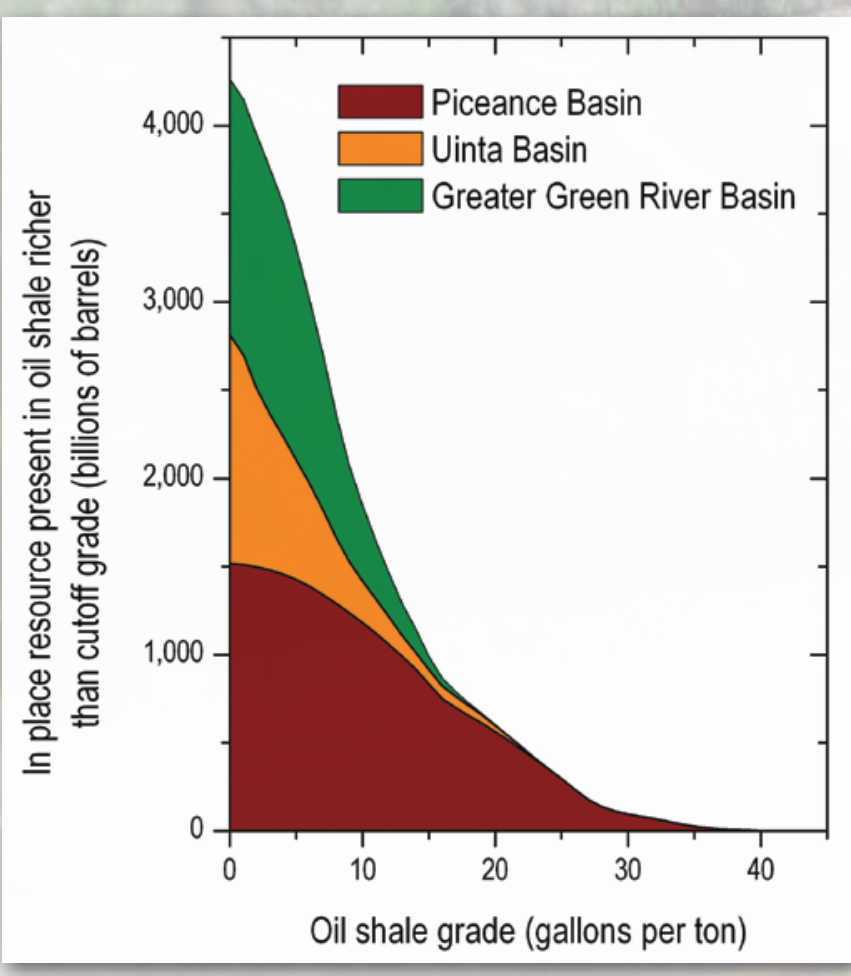

Figure 4. Complimentary cumulative distribution plot for the oil shale resource in-place in the principal basins of the Green the overall distribution for the entire Green River Formation.

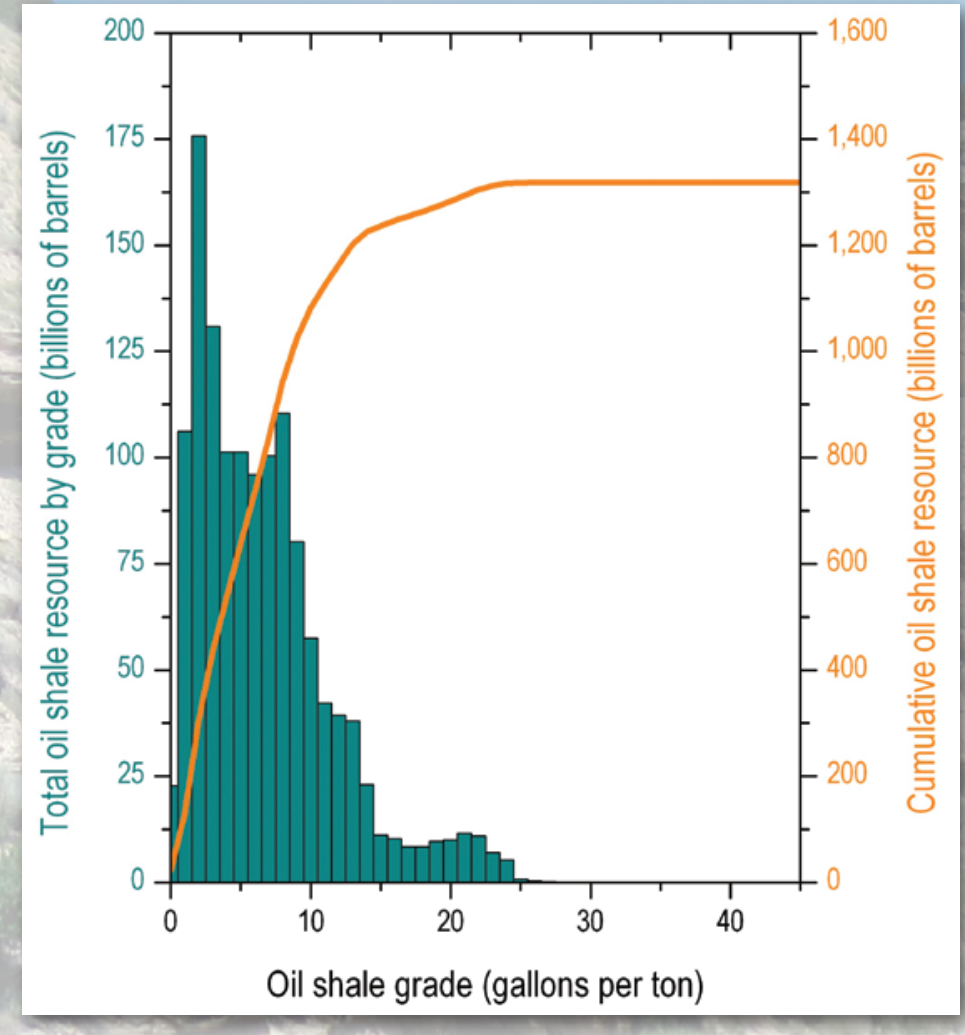

Figure 2. Oil shale resource in-place distribution plot for the Uint Basin. The bars represent the total resource in the basin for a particular grade. The line represents the cumulative resource in place that includes all resource up to a particular grade.

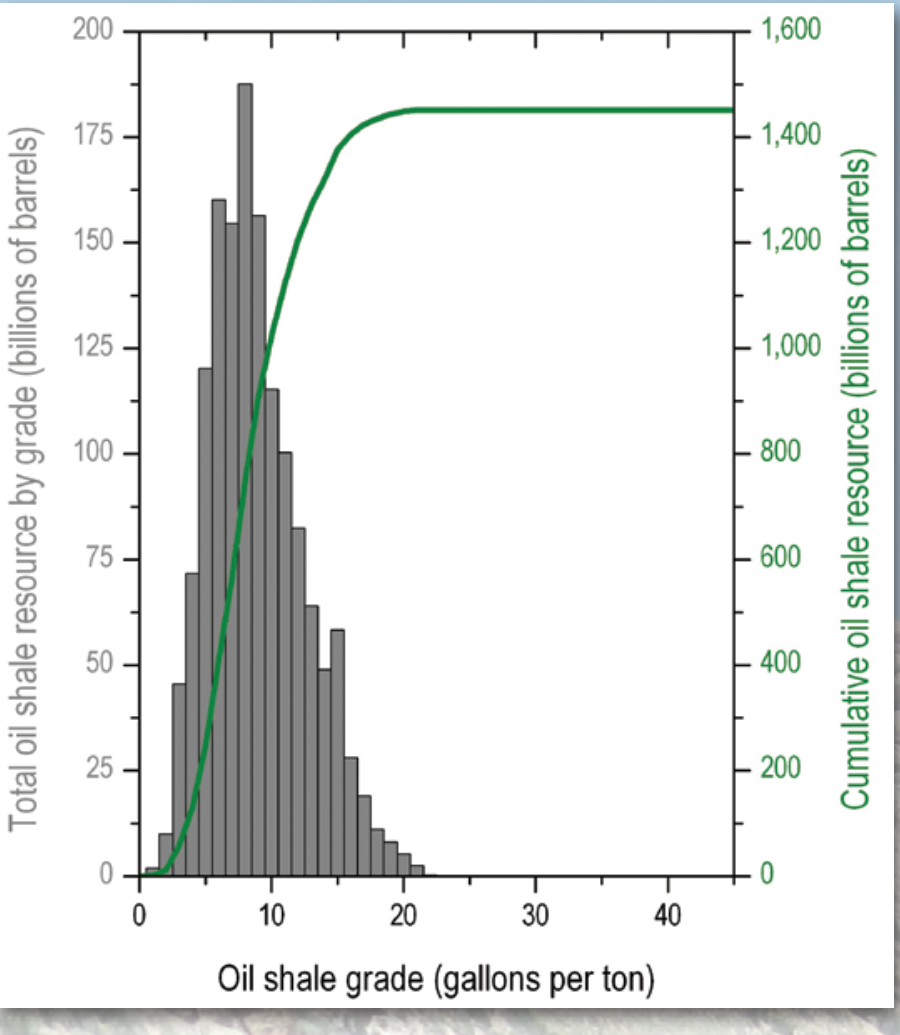

Figure 3. Oil shale resource in-place distribution plot for the Greater Green River Basin. The bars represent the total resource in the basin for a particular grade. The line represents the cumulative
place that includes all resource up to a particular grade.

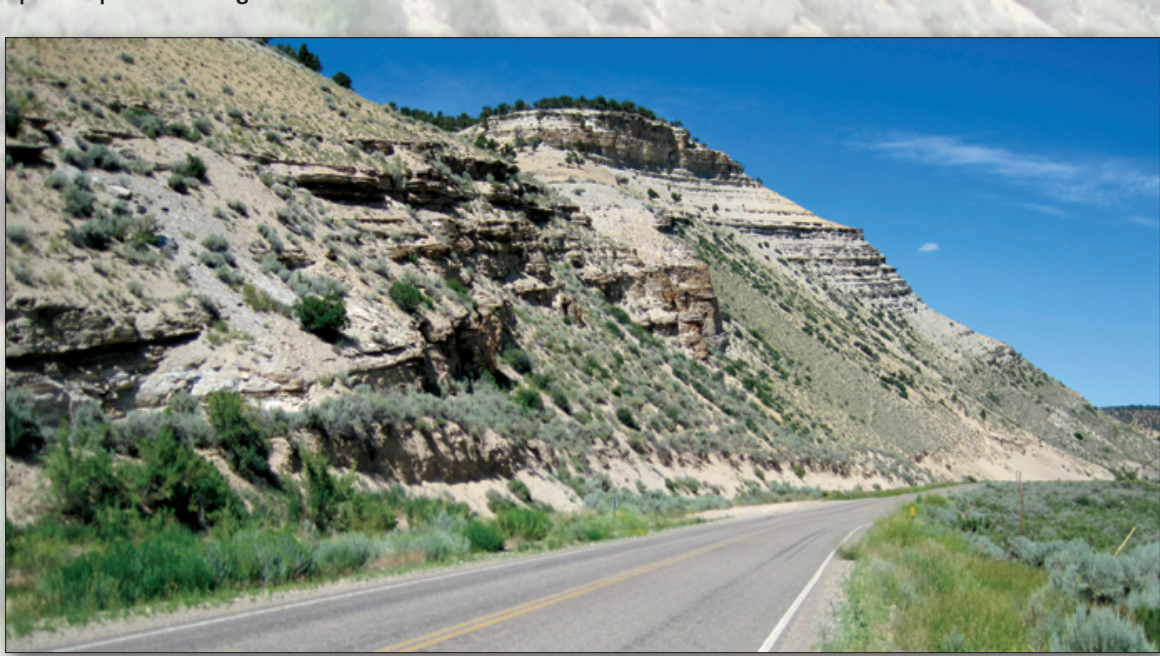

Table 1. Dil shale resources in the principal basins of the Eocene Green River Formation.

[Resource figures are in billions of barrels; --, no resource meets criteria]

\begin{tabular}{|lccccc|}
\hline & $\begin{array}{c}\text { Total resource } \\
\text { in-place }\end{array}$ & \multicolumn{2}{c}{$\begin{array}{c}\text { Oil vield of 15 gallons per ton } \\
\text { (GPT) or greater }\end{array}$} & \multicolumn{2}{c|}{$\begin{array}{c}\text { Oil vield of 25 gallons per ton } \\
\text { (GPT) or greater }\end{array}$} \\
\cline { 3 - 6 } & & $\mathbf{0 i l}$ in-place & $\begin{array}{c}\text { As percent of total } \\
\text { in-place }\end{array}$ & 0il in-place & $\begin{array}{c}\text { As percent of total } \\
\text { in-place }\end{array}$ \\
\hline Piceance Basin & $1,525^{1}$ & 920 & 60 & 352 & 23 \\
Uinta Basin & $1,320^{2}$ & 93.6 & 7 & 1.3 & 0.1 \\
Greater Green River Basin & $1,440^{3}$ & 133 & 9 & -- & 0 \\
Total & 4,285 & 1,146 & 27 & 353 & 8 \\
\hline
\end{tabular}

'Johnson and others, 2010a
Discussion

Comparing the overall grade distributions to those deter(data not shown) shows that the Mahogany zone oil shale represents the largest proportion of high-orade oil shale in the Piceance and Uinta Basins (108 billion and 1.3 billion barrels, respectively). Other notable zones in the Piceance Basi containing substantial amounts of high-grade oil shale resource are the R-4 (71.7 billion barrels), R-5 (61.3 billion barrels), and R-6 ( 36.5 billion barrels) zones, whereas in the Uinta Basin only the Mahogany zone represents any significant quantity of high-grade oil shale. None of the Greater Green River Basin zones contains any high-grade oil shale based on the analysis employed here, although it is known that some intervals within the rich zones contain high-grade material.

A significant portion of the Green River Formation oil shale resource in the Piceance Basin (569 billion barrels) is potentially viable, falling between the 15 - and 25-GPT cutoffs, and most is present in the R-1 ( 83.5 billion barrels), R-5 ( 71 billion barrels), R-6 (103 billion barrels), Mahogany (72.7 billion barrels), and Bed 44 ( 92.5 billion barrels) zones. All Piceance Basin rich zones, as well as some of the lean zones, contain significant Mahogny zone contains significant a Rites of poty arber potentially viable oil shale in that basin. Many technologies currently being developed are
expected to be capable of exploiting leaner oil shale along with the high-grade material without incurring significant additional costs. Therefore, the values reported here should be viewed as conservative estimates. However, full recovery (defined as 100 percent of oil yield determined by the Fischer assay) using some of the methods that are under development may not be achieved, in which case, this analysis overestimates the recoverable resource. It is also possible that measuring oil yield with the Fischer assay may not be the standard for resource recovery in the future. Some alternate approaches that use other criteria include (1) an estimate of total petroleum product (oil and hydrocarbon gases), (2) use of a weight or heating value basis, or (3) an assessment of energy return on investment using a thermodyamic analysis of the potential energy of the resource, the energy required to generate the products, and the energy generated by those products.

Future work to further refine the estimate of recoverable oil shale resources in the Green River Formation will include analysis of how shale oil is likely to be produced based

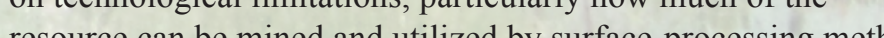
ods and how much can be developed through the application of in situ retorting technologies. At present, however it is uncertain as to what level of oil shale development may ultimately be possible in the Green River Formation, given the many variables that bear on the question, or if significant development will ever occur. A 1- to 3-million-barrel-per-day industry may be a realistic scale for utilization of western United States oil shale resources over a period of a few decades (Bartis and others, 2005). However, issues of water usage and electricity needs are likely to be important limiting factors, along with a range of environmental concern. 


\section{References Cited}

American Society for Testing and Materials, 1980, ASTM D3904-90 Test method for oil from oil shale (resource evaluation by the Fischer assay procedure): West Conshohocken, Pa., American Society for Testing and Materials, Annual Book of ASTM Standards [withdrawn 1996].

Bartis, J.T., LaTourrette, Tom, Dixon, Lloyd, Peterson, D.J., and Cecchine, Gary, 2005, Oil shale development in the United States-Prospects and policy issues: Prepared by the Rand Corporation for the U.S. Department of Energy, National Energy Technology Laboratory, 68 p.

Dyni, J.R., 2006. Geology and resources of some world oilshale deposits: U.S. Geological Survey Scientific Investigations Report 2005-5294, 42 p.

Johnson, R.C., Mercier, T.J., Brownfield, M.E., Pantea, M.P., and Self, J.G., 2010a, An assessment of in-place oil shale resources in the Green River Formation, Piceance Basin, Colorado, chapter 1 of Oil shale and nahcolite resources of the Piceance Basin, Colorado: U.S. Geological Survey Digital Data Series 69-Y, 187 p.
Johnson, R.C., Mercier, T.J., Brownfield, M.E., and Self, J.G., 2010b, Assessment of in-place oil shale resources in the Eocene Green River Formation, Uinta Basin, Utah and Colorado, chapter 1 of Oil shale resources of the Uinta Basin, Utah and Colorado: U.S. Geological Survey Digital Data Series 69-BB, $153 \mathrm{p}$.

Johnson, R.C., Mercier, T.J., Ryder, R.T., Brownfield, M.E., and Self, J.G., 2011, Assessment of in-place oil shale resources in the Eocene Green River Formation, Greater Green River Basin, Wyoming, Colorado, and Utah, chapter 1 of Oil shale resources of the Eocene Green River Formation, Greater Green River Basin, Wyoming, Colorado, and Utah: U.S. Geological Survey Digital Data Series 69-DD, 63 p.

U.S. Energy Information Administration, 2012a, International energy statistics - Proved reserves of oil and natural gas for the world [most recent estimates]: U.S. Energy Information Administration, Independent Statistics and Analysis, accessed June 28, 2012, at http://www.eia.gov/cfapps/ipdbproject/ iedindex3.cfm?tid $=5 \&$ pid $=57 \&$ aid $=6 \&$ cid $=w w, \&$ syid $=2008$ \&eyid $=2012$ \&unit $=B B$.

U.S. Energy Information Administration, 2012b, International energy statistics: U.S. Energy Information Administration, Independent Statistics and Analysis, accessed June 28, 2012, at $h t t p: / / w w w . e i a . g o v / c f a p p s / i p d b p r o j e c t / I E D I n d e x 3$. cfm? tid $=5 \&$ pid $=54 \&$ aid $=2$.

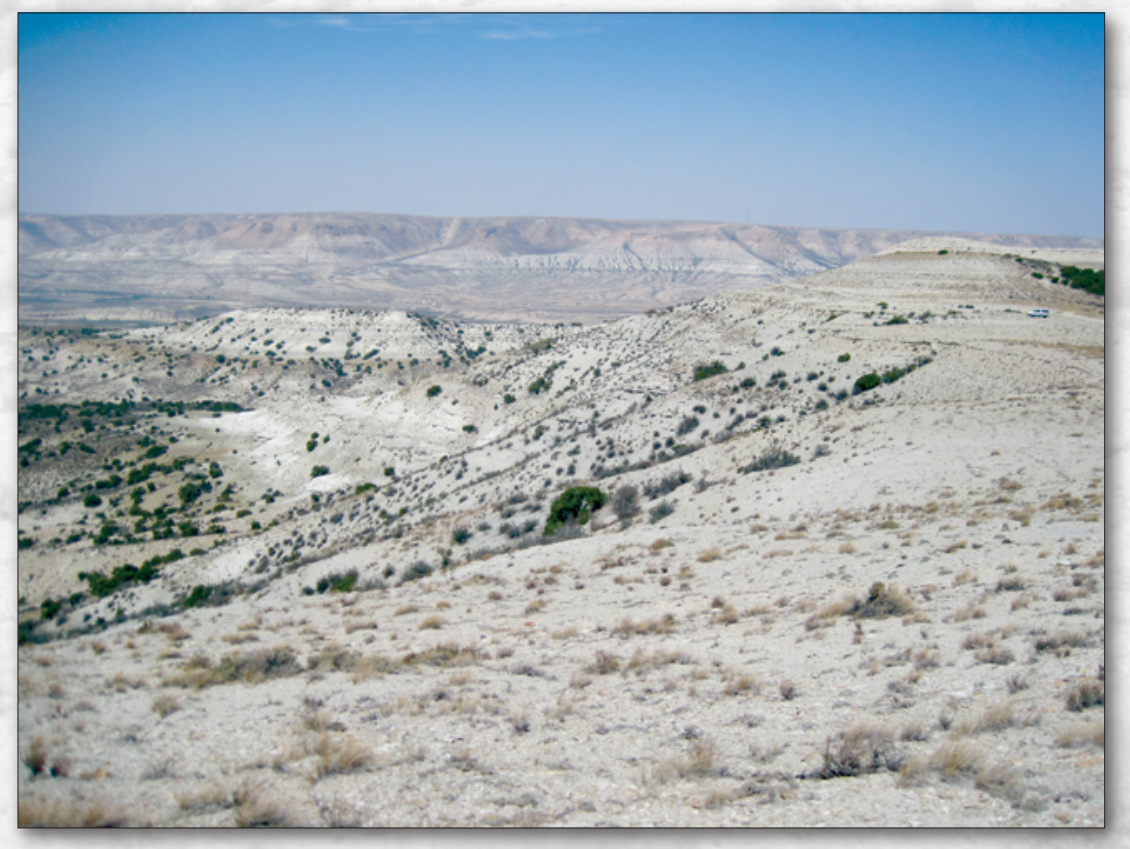

By Justin E. Birdwell, Tracey J. Mercier, Ronald C. Johnson, and Michael E. Brownfield U.S. Geological Survey

Denver Federal Center

Box 25046, MS 977

Denver, CO 80225 